\title{
Self Regulation, Emotional Intelligence With Character Building In Elementary School
}

\author{
Yulia Elfrida Yanty Siregar, Zulela M S, \\ Prayuningtyas A W, Reza Rachmadtullah \\ Department of Elementary Education \\ State University of Jakarta \\ Jakarta, Indonesia \\ Yulyasiregar@gmail.com
}

\author{
Nirwana Pohan \\ Teacher of Elementary \\ Elementary in Aceh \\ Aceh, Indonesia
}

\begin{abstract}
This study aims to describe the effect of selfregulation, emotional intelligence to character building in the fourth grade of elementary school. The sample of the study consisted of 150 student's elementary school from Meuraxa districts in Banda Aceh. This research uses Quantitative method with survey method and correlation technique. The result of this research analysis show (1) existence of positive relation of selfregulation with character formation (2) existence positive correlation of emotional intelligence with character building (3) existence positive relation of self-regulation and emotional intelligence with character building. Emotional intelligence is the higher cognitive so that the individual recognizes, understands, and uses emotions better.
\end{abstract}

Keywords-self regulation; emotional intelligence; character building; elementary school

\section{INTRODUCTION}

Character education describes a developed curriculum to teach children about the essential characteristics needed to build good character. This is one of the deliberate attempts to develop character for individuals and society as a whole [1,2].

Hoge [3] defines character education as an open or conscious effort to influence the development of the desired nature or quality of the individual.

EI is more important than IQ. Emotional intelligence is a rare concept; this is an academic phenomenon and is becoming popular which has resulted in extensive literature [4].

In the definition, emotional intelligence is a higher cognitive that allows individuals to better understand, understand, and use emotions [5].

Social intelligence in children as the ability to understand and manage in acting wisely in human relationships and the surrounding environment. Schools need attention not only about students' cognitive development but also about social and emotional development [6].

Curriculum 2013 and the process of learning Citizenship Education in Elementary School is one focus as an effort to build the character of students. It deals with teaching students to develop the ability to decide how to behave in the right way in various social situations in order to develop individuals who are able to understand moral values and who choose to do the right thing.

Learning activities Citizenship Education in Elementary School oriented to the formation of competence of learners in accordance with the development of psychological, intellectual, emotional and social [7]. Komalasari [8] in his research argues that civic education is oriented towards "contextual plural intelligence" Concepts that open minds about more creative, active-participatory, and meaningful and enjoy able learning needs.

The main key is to educate the EI development in two minds with a focus on how cognitive and emotional mind [9]. Intelligent emotional behavior is reflected in the ability to think constructively and behave wisely. Behavior wise and effective requires the ability to organize and express emotions in a healthy way. EI skills align the cognitive and emotional mind and are essential for effective behavior.

\section{THEORITICAL}

\section{A. Emotional Intelligence (EI)}

The five domains of EI (emotional intelligence), namely self-awareness, managing emotions, motivating oneself, empathy and dealing with relationships, which helps to understand emotional learning in private [10]. There are details of five of these characteristics because it has a high EI:

- Self-awareness is knowing and about the emotions of a person.

- Managing emotions or mood management is able to manage feelings for the present situation and take action appropriately.

- Self-motivation is to direct yourself to a good goal, regardless of doubt.

- A sense of empathy that recognizes the feelings of others and turns them into verbal and non-verbal cues.

- Managing relationships is managing interpersonal interaction, maintaining good relationships with others and being able to negotiate with the surrounding environment. 
Steps to assess EI [11,12] (1) Personal competence with regard to (a) Self-awareness: Recognizing and understanding emotions while in a situation; and (b) Self-management: Using self-emotional awareness to manage responses to different situations and people. (2) Social competence, including: (a) Social awareness: Understanding others' perspectives including the motivations, emotions and meanings of what they do and say; and (b) Relationship management: Using awareness of one's own emotions and emotions to manage relationships with successful outcomes.

EI has a long lasting impact and it is becoming very important to many parents and educators are concerned with the increasing levels of conflict on children. The conceptualization of emotional intelligence encompasses three types of mental processes, judgments, and expressions of emotional intelligence that surround three types of mental processes: emotional assessment and expression, emotional regulation, and emotional utilization [11].

The development of the EI is to educate two minds with a focus on how cognitive and emotional thinking works reflected in the ability to think constructively and behave wisely A wise and effective behavior requires the ability to organize and express emotions in a good way, EI skills align the cognitive and emotional mind to behave effectively [9].

\section{B. Self Regulation}

Self-regulation refers to the ability to change one's behavior [13]. Self-regulation consists of three phases: top-down, reflection and bottom up. Zimmerman [14] self-regulation consists of three top-down phases, reflection and bottom-up. The first stage is the previous thinking, top-down processing by setting learning goals. The second stage is performance. During this phase of learning use bottom-up processing by monitoring one progress by realizing one cognition, motivation, and behavior [15]. The third stage is self-reflection. At this stage students judge a performance and determine what works and what can be improved in order to get better [16].

A person's behavior needs to possess high emotional intelligence. A person with high intelligence (EI) and strong self-regulatory skills will assist them in academics and interact with others [17].

Emotional awareness and self-control, positive thinking, empathy, and compassion for others are all related to emotional intelligence.

\section{Building Character}

Schools have an important role to play in the development of children social and emotional growth. Educators must find ways to infuse the curriculum with character building [18].

Character is a behavior that is shown externally to form individual traits. Individual characters have been shaped by the selection of moral cognition, the emotion expressed in behavior. The character that entrapment allows human beings to consider moral, emotional and action in certain contexts [19].
Character education describes curriculum developed to teach children about essential traits needed to build good character. It is a deliberate effort to develop noble character and cultivate core virtues that are worthy for the individual and society as a whole. It requires careful, calculated planning for success $[1,2]$. It deals with teaching students to develop the ability to decide how to behave in an appropriate manner in various social situations with the purpose of developing individuals who are capable of understanding moral values and who choose to do the right thing [20].

\section{METHOD}

This study aims to describe and examine the effect of selfregulation variables, emotional intelligence with character formation. The research method used quantitative method, with population of all fourth grade students in Meuraxa district Banda Aceh, then 150 students as research sample. The selection of research samples using random sampling. This study uses Likert scale, and implemented in Meuraxa districts school of Banda Aceh. This research using correlation by using SPSS version 24. The research design as follows fig. 1:

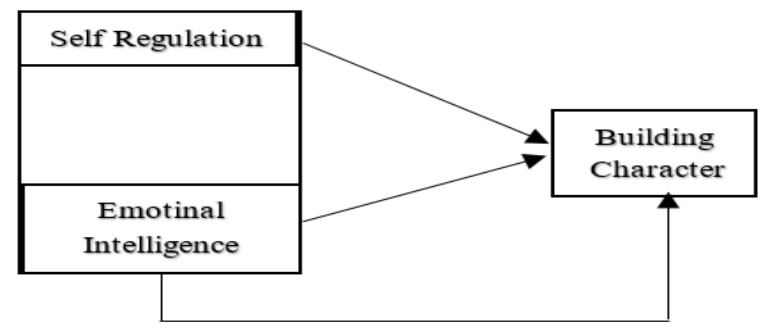

Fig. 1. Design Constellation of Variabel.

\section{RESULT AND DisCUSSION}

The hypothesis of this research is (1) the influence of selfregulation with building character, (2) the influence of emotional intelligence with building character, (3) selfregulation and emotional intelligence with character building. Based on the calculation results obtained data as follows table 1 and table 2:

TABLE I. DESCRIPTIVE STATISTICS

\begin{tabular}{|l|l|l|l|}
\hline & \multicolumn{1}{|c|}{ Mean } & Std. Deviation & \multicolumn{1}{c|}{ N } \\
\hline Building Character & 77,42 & 6,994 & 150 \\
\hline Self Regulation & 75,01 & 6,644 & 150 \\
\hline Emotional Inteligence & 76,65 & 6,501 & 150 \\
\hline
\end{tabular}

TABLE II. RESULT OF COEFFICIENTS VARIABEL $X_{1}$ AND $X_{2}$

\begin{tabular}{|c|c|c|c|c|c|c|}
\hline & \multirow[b]{2}{*}{ Model } & \multicolumn{2}{|c|}{$\begin{array}{l}\text { Unstandardized } \\
\text { Coefficients }\end{array}$} & \multirow{2}{*}{\begin{tabular}{|c|}
$\begin{array}{c}\text { Standardized } \\
\text { Coefficients }\end{array}$ \\
Beta
\end{tabular}} & \multirow[b]{2}{*}{$\mathbf{T}$} & \multirow[b]{2}{*}{ Sig. } \\
\hline & & $B$ & Std. Error & & & \\
\hline 1 & (Constant) &,- 673 & 2,302 & &,- 292 & 770 \\
\hline & Self Regulation & 250 & 073 & 237 & 3,431 & 001 \\
\hline & \begin{tabular}{|l|} 
Emotional \\
Inteligence
\end{tabular} & 774 &, 074 &, 720 & 10,40 &, 000 \\
\hline
\end{tabular}

Regression Equation: $\mathrm{Y}=-0.673+0.250 \mathrm{X} 1+0.774 \mathrm{X} 2$. From the results of the analysis presented in the table 2 , 
obtained the price: $\mathrm{t} 1=3,431 ; \mathrm{db}=146$, $\mathrm{p}$-value $=0.001 / 2=$ $0.0005<0.05$, or $\mathrm{H}_{\mathrm{o}}$ is rejected. Thus: Self-regulation positively influence with building character. From the results of the analysis presented in the table 2 , obtained the price: $\mathrm{t} 2=$ 10,$401 ; \mathrm{db}=146, \mathrm{p}$-value $=0,000 / 2=0,000<0,05$, or Ho rejected. Thus: Emotional Intelligence positively influence with building character.

TABLE III. RESULT OF REGRESSION

\begin{tabular}{|c|c|c|c|c|c|c|}
\hline \multicolumn{2}{|r|}{ Model } & \multirow{2}{*}{\begin{tabular}{|l} 
Sum of Squares \\
6468,366
\end{tabular}} & Df & \multirow{2}{*}{\begin{tabular}{|l|} 
Mean Square \\
3234,183
\end{tabular}} & \multirow{2}{*}{$\begin{array}{r}\mathbf{F} \\
579,66\end{array}$} & \multirow{2}{*}{\begin{tabular}{|r} 
Sig. \\
, $000^{\mathrm{b}}$
\end{tabular}} \\
\hline 1 & Regression & & 3 & & & \\
\hline & Residual & 820,174 & 146 & 5,579 & & \\
\hline & Total & 7288,540 & 149 & & & \\
\hline
\end{tabular}

From the table 3 obtained the price $\mathrm{Fo}=579.66, \mathrm{db}=$ (3,146), p-value $=0.00<0.05$, Ho rejected: Thus: SelfRegulation and Emotional Intelligence positively influence with building character.

TABLE IV. RESULT OF CORELATION

\begin{tabular}{|c|c|c|c|c|c|c|}
\hline \multirow[b]{2}{*}{$\mathbf{R}$} & \multirow[b]{2}{*}{$\begin{array}{c}\mathbf{R} \\
\text { Square }\end{array}$} & \multirow[b]{2}{*}{$\begin{array}{l}\text { Adjusted } \\
\text { R Square }\end{array}$} & \multirow[b]{2}{*}{$\begin{array}{l}\text { Std. Error of } \\
\text { the Estimate }\end{array}$} & \multicolumn{3}{|c|}{ Change Statistics } \\
\hline & & & & $\begin{array}{c}R \text { Square } \\
\text { Change }\end{array}$ & F Change & $\begin{array}{c}\text { Sig. F } \\
\text { Change }\end{array}$ \\
\hline $942^{\mathrm{a}}$ &, 887 &, 886 & 2,362 &, 887 & 579,663 &, 000 \\
\hline
\end{tabular}

From the analysis presented in the table 4 , obtained the price: $\mathrm{R} 2=0.887, \mathrm{Fo}=579,663, \mathrm{db}=(3,146) ; \mathrm{p}$-value $=0,000$ $<0,05$ or Ho is rejected. Thus: The influence of Self-Regulation and Emotional Intelligence positively influence with the building character of 0.887 or $88.70 \%$.

Based on the results of these calculations in a finding that there is a positive relationship between self-regulation and emotional intelligence to build character in elementary school students. These findings are also reinforced because selfregulation is the ability of individuals to adjust their cognition, emotion, and character behavior to meet intrinsic and extrinsic demands [21]. Self-regulated behavior within the context of classes is supposed to involve the cognitive and basic affective executive control functions [22,23]. In the self-regulatory literature, two main competing theories concern self-regulatory structures $[24,25]$. The first theory assumes that self-regulation is a common-domain ability without a clear differentiation between components such as emotional self-regulation and behavior [25,26,27]. From this perspective, a similar process is common in all self-regulatory domains [28], and self-regulation is regarded as a limited shared resource in behavioral, emotional, and cognitive domains [25,26]. Thus, the development of self-regulation of behavior and emotions during primary school has focused on the external social aspects, and the most prominent parenting style needs to be more thoroughly examined.

\section{CONCLUSION}

Based on the results of data analysis can be concluded:

- Self-regulation positively influence with building character.

- Emotional Intelligence positively influence with building character.

- Self-Regulation and Emotional Intelligence positively influence with building character.

- Influence of Self-Regulation and Emotional Intelligence have positive effect with building character equal to 0,887 or $88,70 \%$.

- Self-regulation is an ability possessed by the individual in controlling behavior, and manipulates a behavior by using the ability of his mind so that the individual can react to his environment.

- Self-regulation and emotional intelligence the basis of the socialization process as it relates to all domains in physical, cognitive, social, and emotional development.

\section{REFERENCES}

[1] Prestwich, D. L., Character Education in America's Schools. School Community Journal, 14(1), 139-150. 2004.

[2] Tyra, C., Bringing books to life: Teaching character education through children's literature. Rising Tide, 5, 1-10. 2012.

[3] Hoge, J. D., Character education, citizenship education, and the social studies. The social studies, 93(3), 103-108. 2002.

[4] Harriss, I., Emotional intelligence in the age of liquid modernity: a cultural construct for the 21st century. 2005.

[5] Bay, D., and McKeage, K., Emotional intelligence in undergraduate accounting students: Preliminary assessment. Accounting Education: an international journal, 15(4), 439-454. 2006.

[6] Durlak, J. A., Weissberg, R. P., Dymnicki, A. B., Taylor, R. D., and Schellinger, K. B., The impact of enhancing students' social and emotional learning: A meta-analysis of school-based universal interventions. Child development, 82(1), 405-432. 2011.

[7] W. A. A. Sapriya, Teori dan landasan pendidikan kewarganegaraan. 2011.

[8] Komalasari, K., The effect of contextual learning in civic education on students' civic skills. Educare, 4(2). 2016.

[9] Basu, A., and Mermillod, M., Emotional Intelligence and SocialEmotional Learning: An Overview. Online Submission, 1(3), 182-185. 2011.

[10] Salovey, P., and Mayer, J. D., Emotional intelligence. Imagination, cognition and personality, 9(3), 185-211. 1990.

[11] Mayer, J. D., Caruso, D. R., and Salovey, P., Selecting a measure of emotional intelligence: The case for ability scales. 2000.

[12] Petrides, K. V., and Furnham, A., Gender differences in measured and self-estimated trait emotional intelligence. Sex roles, 42(5-6), 449-461. 2000.

[13] Baumeister, R. F., and Vohs, K. D., Self-Regulation, ego depletion, and motivation. Social and personality psychology compass, 1(1), 115-128. 2007.

[14] Zimmerman, B. J., Investigating self-regulation and motivation: Historical background, methodological developments, and future prospects. American educational research journal, 45(1), 166-18. 2008. 
[15] Schunk, D. H., Self-regulated learning: The educational legacy of Paul R. Pintrich. Educational psychologist, 40(2), 85-94. 2005.

[16] Zimmerman, B. J., Attaining self-regulation: A social cognitive perspective. In Handbook of self-regulation (pp. 13-39). 2000.

[17] O'Brien, M., Miner Weaver, J., Nelson, J. A., Calkins, S. D., Leerkes, E. M., and Marcovitch, S., Longitudinal associations between children's understanding of emotions and theory of mind. Cognition and emotion, 25(6), 1074-1086. 2011.

[18] McElmeel, S. L., Character Education: A Book Guide for Teachers, Librarians, and Parents. Libraries Unlimited. 2002.

[19] Goldberg, J. C., The effects of a character education program on teacher and students perceptions of classroom climate and prosocial development. 2004.

[20] Almerico, G. M., Building Character through Literacy with Children's Literature. Research in Higher Education Journal, 26. 2014.

[21] McClelland, M. M., Ponitz, C. C., Messersmith, E. E., and Tominey, S. Self-regulation: Integration of cognition and emotion. The Handbook of Life-Span Development. 2010
[22] Blair, C., and Ursache, A., A bidirectional model of executive functions and self-regulation. Handbook of self-regulation: Research, theory, and applications, 2, 300-320. 2011. 2012.

[23] Hofmann, W., Schmeichel, B. J., and Baddeley, A. D., Executive functions and self-regulation. Trends in cognitive sciences, 16(3), 174180.

[24] Cicchetti, D., and Tucker, D., Development and self-regulatory structures of the mind. Development an psychopathology, 6(4), 533-549. 1994.

[25] Muraven, M., and Baumeister, R. F., Self-regulation and depletion of limited resources: Does self-control resemble a muscle?. Psychological bulletin, 126(2), 247. 2000.

[26] Berkman, E. T., Graham, A. M., and Fisher, P. A., Training self-control: A domain-general translational neuroscience approach. Child Development Perspectives, 6(4), 374-384. 2012.

[27] Kopp, C. B., Antecedents of self-regulation: a developmental perspective. Developmental psychology, 18(2), 199. 1982.

[28] Heatherton, T. F., Neuroscience of self and self-regulation. Annual review of psychology, 62, 363-390. 2011. 